\title{
Nilai Edukatif Dalam Pelatihan Paduan Suara Pemuda di Jemaat Gereja Masehi Injili di Minahasa Getsemani Paal IV Manado
}

\author{
${ }^{1}$ Ebenhaezer Katihokang, ${ }^{2}$ Alrik Lapian, ${ }^{3}$ Stefanny M. Pandaleke \\ Institut Agama Kristen Negeri Manado \\ 1ebenhaezer.katihokang@gmail.com, 2alriklapian@yahoo.com, ${ }^{3}$ stefanny@iakn- \\ manado.ac.id
}

\begin{abstract}
Abstrak
Paduan suara pemuda Jemaat GMIM Getsemani Paal IV Manado merupakan salah satu wadah yang dibentuk dengan tujuan untuk menampung dan mengembangkan talenta dalam bermusik bagi para pemuda juga sebagai sarana untuk menunjang peribadatan dalam Jemaat. Kehadiran paduan suara ini berdampak positif pada anggota paduan suara, antara lain timbulnya kesadaran tentang disiplin waktu selama proses pelatihan, kemampuan bersosialisasi, dampak terhadap kesehatan fisik maupun spiritualitas serta kemampuan musikal baik itu membaca notasi juga kualitas bernyanyi dari hari ke hari mengalami peningkatan dan makin baik. Penelitian ini bertujuan untuk mendeskripsikan nilai edukatif dalam pelatihan paduan suara serta menganalisis dan menjelaskan nilai edukatif yang terimplementasi dalam proses pelatihan paduan suara pemuda di Jemaat GMIM Getsemani Paal IV Manado. Penelitian ini menggunakan metode kualitatif deskriptif. Hasil penelitian menunjukkan bahwa terdapat nilai edukatif dalam pelatihan paduan suara pemuda. Nilai-nilai tersebut adalah: pembentukan nilai spiritual, pembentukan nilai emosi/karakter, pembentukan nilai intelektual dan pembetukan nilai fisik. Berdasarkan penelitian dapat disimpulkan bahwa kehadiran kelompok paduan suara pemuda sangat berdampak pada perilaku pemuda itu sendiri karena terdapat nilai edukatif yang diperoleh dalam proses pelatihan.
\end{abstract}

Kata kunci: Nilai Edukatif, Pelatihan Paduan Suara, Pemuda

\begin{abstract}
The youth choir of the GMIM Getsemani Paal IV Manado Congregation is one of the forums that was formed with the aim of accommodating and developing musical talents for young people as well as a means to support worship in the congregation. The presence of this choir has a positive impact on choir members, including the emergence of awareness about time discipline during the training process, social skills, the impact on physical health and spirituality as well as musical ability, both reading notation and singing quality from day to day increasing and getting better. . This study aims to describe the educational value in choir training and analyze and explain the educational value implemented in the youth choir training process at the GMIM Getsemani Paal IV Congregation in Manado. This research uses descriptive qualitative method. The results showed that there was educational value in youth choir training. These values are: the formation of spiritual values, the formation of emotional/character values, the formation of intellectual values and the formation of physical values. Based on the research, it can be concluded that the presence of a youth choir has a great impact on the behavior of the youth themselves because there is educational value obtained in the training process.
\end{abstract}

Keywords: Educational Value, Choir Training, Youth 


\section{Pendahuluan}

Setiap kegiatan pasti memiliki tujuan. Begitu juga dengan kegiatan dalam bidang seni. Menurut Jakob Sumardjo ${ }^{1}$, tujuan seni adalah agar masyarakat dapat memetik manfaat, baik secara etik maupun estetik dan logika. Baik seni untuk masyarakat ataupun seni untuk seni, keduanya sama-sama memiliki manfaat bagi masyarakat. Tujuannya agar masyarakat dapat hidup berdampingan dengan seni yang memberi manfaat. Kegiatan berkesenian itu bisa diwujudkan dalam berbagai bentuk salah satunya adalah pelatihan paduan suara.

Adapun hakikat paduan suara adalah menyanyi bersama secara teratur dan terencana, pada waktu dan tempat tertentu secara rutin. $^{2}$ Paduan suara merupakan salah satu kelompok musikal yang sering dijumpai, misalnya dalam Ibadah Jemaat karena fungsinya sebagai penunjang peribadatan. Paduan Suara atau koor (dari Bahasa Belanda, koor) merupakan istilah yang merujuk kepada ensembel musik yang terdiri atas penyanyi-penyanyi maupun musik yang dibawakan oleh ensembel tersebut. Paduan suara merupakan himpunan dari sejumlah penyanyi yang dikelompokkan menurut jenis suaranya. ${ }^{3}$ Paduan suara merupakan

\footnotetext{
1 Jakob Sumardjo. Filsafat Seni. (Bandung: Penerbit ITB, 2000).

${ }^{2}$ Tim Pusat Musik Liturgi, Membina Paduan Suara Jilid 3. (Yogyakarta: PML, 1978)

${ }_{3}^{3}$ Binsar Sitompul, Paduan Suara dan Pemimpinnya, (Jakarta: PT. BPK Gunung Mulia, 1988)
}

satuan vokal yang dalam penampilannya terbagi menjadi beberapa jalur suara, masing-masing suara sopran, alto, tenor, dan bass. ${ }^{4}$

Kehadiran kelompok paduan suara dalam satu Jemaat di samping sebagai penunjang peribadatan juga sebagai sarana edukasi bagi mereka yang terlibat dalam kegiatan tersebut. Nilai edukatif diperoleh selama proses pelatihan berlangsung dari perekrutan sampai pementasan.

Sutarjo Adisusilo ${ }^{5}$ mengatakan, nilai berasal dari bahasa Latin vale're yang artinya berguna, mampu akan, berdaya, berlaku, sehingga nilai diartikan sebagai sesuatu yang dianggap baik, bermanfaat dan paling benar menurut keyakinan seseorang atau sekelompok orang. Menurut Steeman sebagaimana dikutip oleh Eka Darmaputera, nilai adalah sesuatu yang memberi makna pada hidup, yang memberi acuan, titik tolak dan tujuan hidup. Nilai adalah sesuatu yang dijunjung tinggi, yang dapat mewarnai dan menjiwai tindakan seseorang. Nilai itu lebih dari sekedar keyakinan. Nilai selalu menyangkut pola pikir dan tindakan, sehingga ada hubungan yang sangat erat

\footnotetext{
4 Pono Banoe, Kamus Musik, (Yogyakarta: Kanisius, 2003)

${ }^{5}$ Sutarjo Adisusilo, J.R, Pembelajaran Nilai-nilai Karakter Konstruktivisme dan VCT Sebagai Inovasi Pendekatan Pembelajaran Afektif, (Jakarta: Rajawali Pers, 2012)
} 
antara nilai dan etika. ${ }^{6}$ Sedangkan edukatif menurut Kamus Besar Bahasa Indonesia (KBBI) adalah bersifat mendidik; berkenaan dengan pendidikan. ${ }^{7}$ Edukatif masuk dalam kelompok kata sifat, kata bendanya adalah edukasi. Edukasi atau pendidikan secara etimologi berasal dari bahasa Romawi 'educate' yang berarti mengeluarkan sesuatu yang berada di dalam. Dalam bahasa Inggris diistilahkan dengan education yang berarti proses pengajaran, latihan dan pembelajaran. ${ }^{8}$ Jadi, dapat disimpulkan bahwa nilai edukatif ialah batasan segala sesuatu yang mendidik ke arah kedewasaan sehingga berguna bagi kehidupan, yang diperoleh melalui proses pendidikan. Proses pendidikan dapat dilakukan dalam satu tempat dan suatu waktu. Adapun wadah pendidikan dapat berupa sekolah dan juga dapat dilakukan dalam bentuk pelatihanpelatihan.

Demikian halnya dalam konteks pelayanan gereja, kelompok paduan suara juga dapat dijadikan sebagai sarana pengimplementasian nilai edukatif sebagaimana yang dimaksudkan di atas. Di Jemaat Gereja Masehi Injili di Minahasa (GMIM) Getsemani Paal IV Manado terdapat salah satu organisasi yang bertujuan untuk menampung dan mengembangkan talenta dalam bermusik

6 Eka Darmaputera, Pancasila: Identitas dan Modernitas, (Jakarta: BPK Gunung Mulia, 1987), bagi para pemuda. Kelompok ini dibentuk tahun 2000 dan diawasi langsung oleh Komisi Pelayanan Kategorial Pemuda Jemaat karena seluruh anggotanya adalah anggota pemuda di jemaat tersebut. Kelompok tersebut adalah Paduan Suara Pemuda. Paduan suara ini juga bertujuan untuk menunjang peribadatan dalam jemaat. Setiap hari-hari raya besar keagamaan kelompok ini sering dilibatkan dalam acara tersebut.

Melalui kelompok paduan suara ini juga nilai edukatif yang dimaksud dapat diimplementasikan guna memberi manfaat bagi perkembangan pemuda itu sendiri serta prestasi yang di raih dari proses pelatihan tersebut. Secara kasat mata dapat diamati ada fenomena yang terjadi dalam proses pelatihan paduan suara, antara lain timbulnya kesadaran tentang disiplin waktu selama proses pelatihan, kemampuan bersosialisasi, dampak terhadap kesehatan fisik maupun spiritualitas serta kemampuan musikal baik itu membaca notasi juga kualitas bernyanyi dari hari ke hari mengalami peningkatan dan makin baik.

\section{Metode}

Penelitian ini menggunakan metode penelitian kualitatif deskriptif, dengan menggunakan pendekatan studi kasus.

7 Depdikbud, (2001). Kamus Besar Bahasa Indonesia

${ }^{8}$ Helmawati, Mengenal dan Memahami PAUD (Bandung: Rosdakarya, 2015) 
Pendekatan studi kasus adalah pendekatan yang mengeksplorasi kehidupan nyata pada suatu kasus atau beragam kasus melalui pengumpulan data yang detail dan mendalam dan melibatkan beragam sumber informasi seperti, observasi, wawancara, bahan audio visual dan berbagai dokumen terkait. ${ }^{9}$

\section{Hasil dan Pembahasan}

Sebagaimana telah dipaparkan dalam uraian sebelumnya bahwa nilai edukatif merupakan batasan segala sesuatu yang mendidik kearah kedewasaan sehingga berguna bagi kehidupan, yang diperoleh melalui proses pendidikan apakah di sekolah atau melalui bentuk kegiatan pelatihan. Artinya bahwa pencapaian dan perwujudan nilai edukatif bukanlah sesuatu yang terwujud secara otomatis dalam kehidupan. Melainkan semua itu harus melalui proses yang berlangsung secara berkesinambungan. Hal ini juga mewujud nyata dalam konteks kegiatan pelatihan paduan suara pemuda jemaat GMIM Getsemani Paal IV. Kekayaan nilai edukatif yang ada dalam konteks kegiatan pelatihan paduan suara pemuda jemaat GMIM Getsemani Paal IV, telah membuktikan bahwa kegiatan pelatihan paduan suara merupakan wadah potensial bagi pembentukan kepribadian pemuda

${ }^{9}$ Jonh W. Creswell, Research Design: Penelitian Kualitatif Kuantitatif dan Campuran, (Yogyakarta: Pustaka Pelajar, 2015) gereja. Sehubungan dengan itu, di bawah ini akan dipaparkan pembahasan tentang nilai edukatif serta bagaimana implementasinya bagi kegiatan pelatihan paduan suara pemuda di jemaat GMIM Paal IV.

\section{Nilai Edukatif}

\section{a. Pembentukan Nilai Spiritual}

Semuel S. Lusi mengungkapkan bahwa spiritualitas atau roh berkaitan dengan visi, visualisasi, daya khayal, déjà vu, impian, harapan dan pengenalan akan unsur transenden. Lusi mengutip pernyataan Dean Hamer bahwa spiritualitas berasal dari dalam diri. Benihnya sudah harus ada sejak awal. Dan benih itu menjadi bagian dari gen. ${ }^{10}$ Menurut Mitologi Yunani kuno seperti yang dikutip oleh Djohan mengatakan bahwa "Musik adalah seni yang dikaruniai kekuatan untuk menembus ke kedalaman jiwa". ${ }^{11}$ Eka Dharmaputra memahami bahwa spiritualitas adalah roh, jiwa, semangat dan gairah. Ibarat gereja yang mempunyai segala sesuatu: gedung gereja, pendeta, kegiatankegiatan, keuangan, aktivitas yang banyak, tetapi tanpa spiritualitas yaitu roh, jiwa, semangat dan

${ }^{10}$ Semuel S. Lusi, The Real You is The Real Success, (Jakarta: Gramedia, 2010). h. 13 Djohan, Psikologi Musik, (Yogyakarta: Kanisius, 2020). hh. 227-228 
gairah, maka semuanya itu akan berubah menjadi sekedar sebuah rutinitas gereja semata. ${ }^{12}$

Demikian halnya dengan pelatihan paduan suara, jika spiritualitas anggota tidak dibangun maka kegiatan pelatihan ini hanya sebatas rutinitas belaka saja. Pembentukan nilai spiritualitas bagi pemuda jemaat GMIM Getsemani Paal IV melalui kegiatan pelatihan paduan suara merupakan sebuah upaya edukatif guna pembentukan spiritualitas pemuda gereja. Melalui kegiatan pelatihan paduan suara, kehidupan spiritual anggota paduan suara pemuda juga dibangun bersama sehingga keberadaan paduan suara ini bukan hanya dijadikan sebagai tempat pengisi waktu saja tetapi dijadikan tempat menumbuhkan nilai-nilai kristiani.

b. Pembetukan Nilai

Emosi/Karakter

Sebagaimana hasil temuan penelitian, dalam pelatihan paduan suara pemuda juga di dapati adanya pembentukan nilai emosi/karekter terhadap anggotanya. Anggota paduan suara yang awalnya belum disiplin, temperamental, suka minum minuman keras dan kurang bersosialisasi berangsur-angsur

${ }^{12}$ Eka Darmaputera, Spiritualitas Siap Juang (Jakarta: BPK Gunung Mulia, 2011), 207. mengalami perubahan dan meninggalkan kebiasaan lamanya. Hal ini disebabkan karena proses pembentukan melalui pelatihan paduan suara dengan adanya aturan-aturan yang disepakati bersama diawal pertemuan/latihan. Pada umumnya anggota mengalami perubahan sikap tersebut. Hal ini diperkuat juga dengan pernyataan dari ketua komisi pemuda dan ketua BPMJ GMIM Getsemani Paal IV.

Sebagaimana yang diungkapkan oleh Thomas Edison bahwa nilai yang dimaksud adalah nilai-nilai kristiani dalam Jemaat menyangkut kekudusan, kejujuran, kesabaran, ketaatan, kedisiplinan, pemberian persembahan, serta sikap suka menolong, mengutamakan kepentingan umum, bertoleransi, mengampuni. ${ }^{13}$

c. Pembentukan Nilai Intelektual

Pembentukan nilai intelektual melalui kegiatan pelatihan paduan suara merupakan sebuah upaya memaksimalkan potensi kognisi pemuda gereja melalui kegiatan musik. Kemampuan ini memungkinkan pemuda gereja untuk dapat memahami perkembangan ilmu pengetahuan di bidang musik, sekaligus dapat

13 Thomas Edison, Pendidikan Nilainilai Kristiani, (Bandung: Kalam Hidup, 2018), h. 142. 
memanfaatkan

berbagai

pengetahuan yang ada untuk dapat melakukan analisis terhadap berbagai persoalan hidup. Jean Marie Stine seperti yang dikutip oleh Semuel L. Lusi mengatakan bahwa memori (ingatan) terbentuk oleh elemen-elemen penglihatan, suara, bau, emosi, dan pikiran yang bergerak melalui saraf yang berakhir di otak. Melalui elemenelemen tersebut, memori terjadi hanya dalam waktu seketika. ${ }^{14}$ Dalam bukunya Psikologi Musik Djohan mengatakan bahwa musik dipercaya dapat membantu anak untuk mengembangkan intelektual, emosi, motor dan keterampilan sosial. ${ }^{15}$

\section{d. Pembentukan Nilai Fisik}

Hal yang tak kalah pentingnya diperoleh dari pelatihan paduan suara adalah adanya pembentukan nilai fisik dari para anggota. Dari aktifitas latihan paduan suara pemuda yang diamati oleh peneliti, setiap latihan selalu ada pemanasan (olah tubuh), latihan pernafasan bahkan sampai melakukan yoga. Hal tersebut membantu pembentukan fisik para anggota bahkan juga berimbas

\footnotetext{
${ }^{14}$ Semuel S. Lusi, The Real You is The Real Success, (Jakarta: Gramedia, 2010)

15 Djohan, Psikologi Musik, (Yogyakarta: Kanisius, 2020). h. 163
}

pada kesehatan seperti yang diungkapkan oleh berapa anggota.

Stephanie

Merritt mengungkapkan setiap kali dia bertanya kepada orang tentang reaksi tubuh mereka saat mendengarkan musik tertentu mereka mengatakan "menyenangkan", "segar", atau "energik". Setelah kita menyadari bahwa musik mengubah fungsifungsi fisik di tubuh kita, barulah kita mulai memperhatikan perubahan detak nadi, kekuatan otot, dan sirkulasi tubuh yang dipicu oleh musik. $^{16}$

2. Implementasi Nilai Edukatif Dalam Pelatihan Paduan Suara.

Kegiatan pelatihan paduan suara dalam konteks pelayanan kategorial pemuda Jemaat GMIM Getsemani Paal IV, telah menjadi salah satu sarana pengintegrasian nilai-nilai Kristiani yang bertujuan untuk membentuk kepribadian pemuda gereja yang seutuhnya. Dengan demikian maka kegiatan pelatihan paduan suara tidak hanya sekedar menjadi wadah penyaluran minat dan bakat pemuda gereja melainkan telah manjadi ruang pembelajaran sekaligus penyadaran tentang nilai dari eksistensi seorang

\footnotetext{
16 Stephanie Merritt, Simfoni Otak,
} (Bandung: Kaifa, 2003). h. 112 
pemuda gereja. Integritas kepribadian pemuda gereja harus diwujudkan dalam bentuk kematangan spiritualitas, intelektualitas, emosionalitas serta pengoptimalisasian segi psikomotorik yang bersumber dari kesehatan fisik pemuda gereja. Dengan demikian dapat dikatakan bahwa kegiatan pelatihan paduan suara bagi pemuda gereja di Jemaat GMIM Getsemani Paal IV, telah menjadi wadah pembentukan keutuhan potensi fisik maupun psikis setiap insan pemuda gereja. Sebab, semua nilai edukatif yang diuraikan diatas dapat terimplementasi dalam kegiatan pelatihan paduan suara mulai dari tahapan pembentukan tim, pada proses latihan bahkan sampai pada saat penampilan kelompok paduan suara. Semua tahapan proses latihan ini menjadi sarana pembentukan serta perwujudan eksistensi pemuda gereja.

Dari segi nilai spiritual, kegiatan pelatihan paduan suara sangat bermanfaat bagi pembentukan spiritualitas pribadi anggota paduan suara. Dimana selama proses pelatihan paduan suara ada peresapan pesan teologis dari setiap nyanyian yang dilatih. Pesan-pesan iman dari teks nyanyian yang dilatih tidak hanya sekedar menjadi bahan hafalan semata, akan tetapi mestinya dijiwai dan diresapi sehingga mampu diaplikasikan dalam praktik hidup.
Dari segi nilai emosi/karakter, proses pelatihan paduan suara telah menjadi medan interaksi sosial antar anggota paduan suara yang berfungsi untuk mengasah serta membentuk kematangan emosional masing-masing pribadi anggota. Interaksi ini memungkinkan terjadinya proses saling memahami dan mengenal karakter kepribadian antara anggota paduan suara. Melalui interaksi yang terjadi dalam latihan ini, terjadi juga perubahan sikap dari anggota paduan suara dalam hal kedisipilinan karena adanya aturan yang dibuat dan disepakati bersama selama proses pelatihan paduan suara. Juga dengan adanya lagu-lagu yang memberikan seruan moralitas menggambarkan bahwa tidak hanya pemahaman teologis saja yang didapat melainkan juga terbentuk moral dan etik pemuda gereja.

Dari segi intelektual, para anggota memperoleh tambahan pengetahuan dibidang musik tentang vokal, membaca notasi musik, sejarah musik, sejarah komposer, yang menyebabkan adanya peningkatan kualitas bernyanyi dari para anggota dari hari ke hari. Bahkan kegiatan pelatihan paduan suara memberi dampak positif dalam studi di sekolah/kampus dimana ada beberapa anggota paduan suara yang mengalami peningkatan prestasi.

Dari segi nilai fisik, selama proses pelatihan paduan suara dengan 
berbagai metode pemanasan (olah tubuh), latihan pernafasan dan yoga membuat para anggota merasa lebih baik dari segi fisik dan berimbas pada kesehatan mereka.

\section{Kesimpulan}

Berdasarkan hasil penelitian tentang nilai edukatif dalam pelatihan paduan suara pemuda di Jemaat GMIM Getsemani Paal IV dapat disimpulkan bahwa:

1. Nilai Edukatif yang diperoleh dalam pelatihan paduan suara adalah: pembentukan nilai spiritual, pembetukan nilai emosi/karakter, pembentukan nilai intelektual dan pembentukan nilai fisik.

2. Implementasi nilai edukatif tersebut diatas dapat ditemui dalam proses pelatihan paduan suara mulai dari penerimaan anggota (recruitmen) sampai pada penampilan/pementasan. Dengan demikian maka kegiatan pelatihan paduan suara tidak hanya sekedar menjadi wadah penyaluran minat dan bakat pemuda gereja melainkan telah manjadi ruang pembelajaran sekaligus penyadaran tentang nilai dari eksistensi seorang pemuda gereja sehingga membentuk pribadi yang lebih dewasa dan berguna bagi kehidupan.

\section{Kepustakaan}

Adisusilo, Sutarjo, J.R, Pembelajaran Nilainilai Karakter Konstruktivisme dan VCT Sebagai Inovasi Pendekatan Pembelajaran Afektif, Jakarta: Rajawali Pers, 2012.

Badan Pekerja Majelis Sinode GMIM, Tata Gereja 2021, Tomohon: Percetakan/Offsed Sinode GMIM, 2021.

Banoe, Pono, Kamus Musik, Yogyakarta: Kanisius, 2003.

Creswell, John W. Research Design: Penelitian Kualitatif Kuantitatif dan Campuran, Yogyakarta: Pustaka Pelajar, 2015

Darmaputera, Eka, Pancasila: Identitas dan Modernitas, Jakarta: BPK Gunung Mulia, 1987.

Spiritualitas Siap Juang, Jakarta: BPK Gunung Mulia, 2011.

Depdikbud, (2001). Kamus Besar Bahasa Indonesia

Hamalik, Oemar, Manajemen Pelatihan Ketenagakerjaan:

Pendekatan Terpadu, Jakarta: PT Bumi Aksara, 2007.

Hasbullah, Dasar-Dasar Ilmu Pendidikan : Pengertian dan Faktor-Faktor Pendidikan, Jakarta: Rajawali Pers, 2015.

Helmawati, Mengenal dan Memahami PAUD, Bandung: Rosdakarya, 2015.

Jamalus dan Mahmud A.T., Musik IV untuk SPG, Jakarta: Departemen Pendidikan dan Kebudayaan, 1981.

Kartika, Ika, Mengelola Pelatihan Partisipatif, Bandung: Alfabeta, 2011.

Lusi Semuel S, The Real You is The Real Success, Jakarta: Gramedia, 2010 

, The Great Transvormation
Starts From You, (Jakarta:
Gramedia, 2013)
Mangkunegara, Prabu Anwar, Evaluasi Kinerja SDM, Bandung: Refika Aditama, 2005.

Mathis, R.L dan Jackson, J.H, Manajemen Sumber Daya Manusia, Jakarta: Salemba Empat, 2002.

Merritt Stephanie, Simfoni Otak, Bandung: Kaifa, 2003

Simamora, Henry, dalam Tim Pengembang IImu Pendidikan FIPUPI, 1995.

Sitompul, Binsar, Paduan Suara dan Pemimpinnya, Jakarta: PT. BPK Gunung Mulia, 1988.

Sumardjo, Jakob. Filsafat Seni, Bandung: Penerbit ITB, 2000.

Sugiyono, Metode Penelitian, Bandung: Alfabeta, 2012.

Edison Thomas, Pendidikan Nilai-nilai Kristiani, Bandung: Kalam Hidup, 2018

Tim Pusat Musik Liturgi, Membina Paduan Suara Jilid 3, Yogyakarta: PML, 1978.

Undang-Undang Republik Indonesia nomor 20 tahun 2003 Tentang Sistim Pendidikan Nasional 